\title{
Single-Species Co-management Improves Fish Assemblage Structure and Composition in a Tropical River
}

\author{
Wendell M. Medeiros-Leal ${ }^{1,2,3 *}$, Leandro Castello ${ }^{4}$, Carlos E. C. Freitas ${ }^{3}$ and \\ Flávia K. Siqueira-Souza ${ }^{3}$
}

${ }^{1}$ MAR Institute of Marine Research, University of the Azores, Horta, Portugal, ${ }^{2}$ Okeanos R\&D Centre, University of the Azores, Horta, Portugal, ${ }^{3}$ Department of Fisheries Sciences, Faculty of Agricultural Sciences, Federal University of Amazonas, Manaus, Brazil, ${ }^{4}$ Department of Fish and Wildlife Conservation, Virginia Polytechnic Institute and State University, Blacksburg, VA, United States

\section{OPEN ACCESS}

Edited by:

Jasmine Lee,

Monash University, Australia

Reviewed by:

Renato Silvano,

Federal University of Rio Grande do

Sul, Brazil

Jaclyn Hill,

Maurice Lamontagne Institute, Fisheries \& Oceans Canada, Canada

*Correspondence:

Wendell M. Medeiros-Leal wendellmedeirosleal@gmail.com

Specialty section:

This article was submitted to Biogeography and Macroecology,

a section of the journal

Frontiers in Ecology and Evolution

Received: 08 September 2020

Accepted: 09 February 2021

Published: 02 March 2021

Citation:

Medeiros-Leal WM, Castello L, Freitas CEC and Siqueira-Souza FK

(2021) Single-Species

Co-management Improves Fish Assemblage Structure and

Composition in a Tropical River.

Front. Ecol. Evol. 9:604170.

doi: 10.3389/fevo.2021.604170
Co-management is increasingly recognized as an effective model for managing fisheries, but little information exists on whether co-management can produce effects in species other than the target species. Fishery co-management in the tropics, where fish diversity is high and fish catches tend to be multispecies, is prone to produce assemblagewide effects via alterations in the food web and changes in the overall capture of non-target species. Here, we assessed the effects of co-management for the species Arapaima sp. in relation to the structure and composition of the overall fish assemblage in floodplain lakes of the central Amazon Basin. These floodplain lakes are managed under a system of zoning of fishing activities. We used data from surveys of six floodplain lakes, including two lakes of each of three categories (lakes where fishing is prohibited, limited-access lakes, and open fishing lakes). The surveys were carried out before and after implementation of co-management, through gillnet fishing. The study area was the lower Solimões River, in the Amazon Basin, Brazil. Statistical models showed significant changes in the composition and structure of the fish assemblages after the implementation of the co-management, regardless of the zoning category. Through regulation of gear use and fishing practices, co-management allowed the colonization of species that had not been present before, which lead to higher richness and consequently increased fish sizes, abundance and biomass. Species of sedentary habits, migrants of short and medium distances, with commercial importance benefited the most from co-management. In the results presented in temporal scale, it was possible to observe a potential spillover effect being provided by the lakes where fishing is prohibited (no-take zones) and those of limited access that benefited those open to fishing. Thus, co-management had positive effects in the structure and composition of fish assemblages in all lakes, regardless of zoning category.

Keywords: biodiversity, fish diversity, fishing agreements, fishery management based on communities, amazonia

Abbreviations: ADAPTA, adaptations of aquatic biota of the amazon; AM, after management; ANOVA, analysis of variance; $\mathrm{BM}$, before management; CAPES, co-ordination for the improvement of higher education personnel; CNPq, Brazilian National Research Council; CPUEn, capture per unit of effort (in number); CPUEw, capture per unit of effort (in weight); FAPEAM, Amazonas State Research Foundation; H', shannon's diversity index; MPAs, marine protected areas; N, numerical abundance; PAPAC, publication of scientific articles support program; PERMANOVA, multivariate analysis of permutational variance; SDS, secretariat for sustainable development; S, species richness; UFAM, Universidade Federal do Amazonas. 


\section{INTRODUCTION}

Since the 1990s, the discussion of co-management in fisheries has intensified. According to Symes (2006), co-management can be defined as systems in which responsibility for management is shared between the state and user groups, usually at the local level. It is important to note that co-management differ from community-based resource management with purely local approaches of self-management by users (Linke and Bruckmeier, 2015). Thus, co-management is being increasingly recognized as an effective model for managing fisheries (Carlsson and Berkes, 2005; Berkes, 2009). Many studies have shown that comanagement tends to increase levels of stakeholder engagement, decrease non-compliance with management rules, and promote sustainable use of target fish resources (Chuenpagdee and Jentoft, 2007; Linke and Bruckmeier, 2015). In biologically diverse environments, due to co-management in terms of the amount of catch, fishing seasons, and gear used in fishing, changes in fisher's behavior can be expected to produce indirect effects on the fish assemblage which hosts the target species. However, little information exists on whether co-management can produce effects in species other than the target species, either in freshwater environments (Silvano et al., 2009; Campos-Silva et al., 2018; Medeiros-Leal et al., 2018) or marine (Gelcich et al., 2008).

For fisheries in tropical environments, where fish diversity is high, the fish catches tend to be multispecies (Mahon, 1997; Welcomme et al., 2010). In these environments, fisheries often exploit as much as 100 or more fish species, and catches of any one species often are accompanied by several more (McClanahan and Mangi, 2004). However, this pattern does not hold in the Amazon Basin due to moderate selectivity of fisheries, where the five preferred species can correspond to more than $50 \%$ (up to $84 \%$ ) of the total catch (Hallwass and Silvano, 2016). This moderate selectivity suggests that fisheries in the Amazon are prime candidates for single-species management initiatives with assemblagewide effects. However, previous studies have emphasized the difficulties of promoting sustainable fisheries in these tropical environments, due to the high diversity of species. That is, the collection of data sufficient for stock assessments become a difficult task and assessment and management approaches need to be fundamentally different to those of large-scale commercial fisheries (Andrew et al., 2007; Lorenzen et al., 2016).

The multispecies nature of these fisheries has been shown to produce adverse effects in species that are historically vulnerable to heavy exploitation and may also affect the structure, composition and functioning of the fish assemblages (Bellwood et al., 2003; Gasparini et al., 2005; Silvano et al., 2009, 2017). Besides that, the fishing down process predicts that increases in fishing effort in these fisheries gradually decrease the average body size of the exploited assemblage and cause a replacement of larger species, which typically have slow growth and low reproductive outputs (e.g., K-strategists), by small, fast-growing species with high reproductive outputs (e.g., r-strategists) (Welcomme, 1999), as observed in some Amazonian rivers (Hallwass et al., 2020). This is different from the fishing down marine food web phenomenon which predicts decreases in trophic levels (Pauly and Christensen, 1993).

A less appreciated aspect of fisheries management in tropical environments, however, is that management efforts targeted at one or more species may improve the status of not only the targeted taxa, but also the status of other species in the exploited fish assemblage. This process can occur via changes in the overall capture of less-target or non-preferred species and trophic cascades. Changes in the amount of fishing effort and catch, restrictions of non-selective fishing gear, seasonal restrictions on fishing, or even the implementation of no-take reserves could decrease harvests of sensitive taxa groups or under-sized specimens, even if they are less-targeted or nonpreferred. Such plausible effects could in turn lead to changes in the overall diversity of species available in these systems, at least locally (Silvano et al., 2009; Soares et al., 2014; Morales et al., 2019). Trophic cascade effects can occur since the abundance of targeted, predatory taxa are maintained at higher levels, thereby affecting the abundance of prey taxa via predation, as has been shown in marine environments (Baum and Worm, 2009). This process can be expected to have a pronounced effect in tropical inland environments where piscivores fish exert the greatest control of the structure and composition of fish communities (Rodríguez and Lewis, 1997). There is, therefore, a likelihood that co-management aimed at single species or groups of target species can produce effects on entire fish assemblages, promoting conservation of fish diversity in the world's most biologically diverse aquatic environments.

The definition of zoning systems with total or partial restriction to fishing, models which have been implemented in the Brazilian Amazon, have been shown in other studies to be an effective way of protecting the biodiversity in marine and continental environments (Russ et al., 2004; Gerber et al., 2005; Castejón and Charles, 2013; Azevedo-Santos et al., 2019). In the Amazon, the implementation of protected areas, through fishing agreements among users of fishing resources, which establish distinct fishing regimes in floodplain lake systems, have been achieving success in the recovery of stocks of the target species in several areas of the Amazon (Almeida et al., 2009; SánchezBotero et al., 2010; Arantes and Freitas, 2016; Campos-Silva and Peres, 2016; Petersen et al., 2016; Keppeler et al., 2017). According to Castro (2000) the Arapaima sp. is the main species that has presented a positive response to these co-management (fishing agreements) systems and since 1999, the fishing agreements have paved the way as a promising single-species co-management tool focused on the sustainable Arapaima sp. exploitation in the Brazilian Amazon (Campos-Silva and Peres, 2016).

Herein, we assessed the effects of co-management when targeted at one fish taxon in relation to the structure and composition of the overall fish assemblage. Our case study analyses the Arapaima sp. co-management scheme implemented in the central Amazon Basin. We assessed fish assemblage data for a group of floodplain lakes during the periods before and after the implementation of the Arapaima sp. co-management policies and under different management regimes, from no-take to open to fishing, to answer two research questions: (i) does the implementation of co-management for the Arapaima sp. affect 
the structure and composition of the fish assemblage? and (ii) do the effects on the fish assemblage vary in floodplain lakes under different management regimes?

\section{MATERIALS AND METHODS}

\section{Case Study and Area}

Our study area was the Paciência Island (approximately $68 \mathrm{~km}^{2}$ of area), located in the lower Solimões River, in Amazonas State, Brazil, which hosts a system of floodplain lakes (Figure 1). The ecosystem in the Paciência Island includes whitewater varzea floodplains, which are key habitats for aquatic biodiversity, including fish (Freitas et al., 2010, 2018; Arantes et al., 2019; Morales et al., 2019) and other groups, such as river turtles of the genus Podocnemis (Podocnemis expansa, Podocnemis unifilis, and Podocnemis sexturbeculata) (Campos-Silva et al., 2017). In the whitewater rivers, such as the Solimões River, the floodplains are highly productive and determine the existence of abundant stocks that have been intensively exploited for over four decades (Batista et al., 1998; Isaac et al., 2016), which has even caused over-exploitation of some stocks (Sant'anna et al., 2014; Campos et al., 2015).

The Arapaima sp. co-management scheme studied here follows a system whereby fishers perform direct counts of Arapaima sp. at the moment of their obligate aerial breathing using a standardized and scientifically validated method (Castello, 2004). In this co-management scheme, locally known as a fishing agreement, the fishers, who are supported by local governmental and non-governmental organizations, use the counts to get conservative fishing quotas (Castello et al., 2009), which are set under the condition that fishers comply with minimum size ( $>1.5 \mathrm{~m}$ total length) and closed season (December-May) rules of harvesting. Fishers seeking a harvest quota must also adhere to a community-wide co-management plan, which in our study sites included a zoning plan regulating use of floodplain resources and the establishment of distinct levels of fishery restrictions in the lakes.

Since 2011, fisheries in Paciência Island are managed by a fishing agreement established by the Ruling Decree $\mathrm{N}^{\circ}$ 02/2011 (SDS, 2011) that encompasses 32 lakes distributed in three categories of fishing restrictions: no-take lakes, limited access lakes, and open fishing lakes. Since then, the population density of Arapaima sp. has increased over the years (Figure 2). The following six floodplain lakes, which belong to three zoning categories of the island's zoning plan, are listed in detail here:

- No-take lakes: Lakes Cacau $\left(03^{\circ} 18^{\prime} 32.9^{\prime \prime} \mathrm{S}\right.$ and $\left.60^{\circ} 12^{\prime} 54.1^{\prime \prime} \mathrm{W}\right)$ and Baixo $\left(03^{\circ} 18^{\prime} 09.0^{\prime \prime} \mathrm{S}\right.$ and $60^{\circ} 13^{\prime} 35.4^{\prime \prime} \mathrm{W}$ ) are lakes intended for the reproduction and development of species, where fishing activities in all modalities are prohibited in order to ensure the preservation of species;

- Limited access lakes: Lakes Sacambu $\left(03^{\circ} 18^{\prime} 46.0^{\prime \prime} \mathrm{S}\right.$ and $\left.60^{\circ} 13^{\prime} 19.0^{\prime \prime} \mathrm{W}\right)$ and Preto $\left(03^{\circ} 18^{\prime} 33.0^{\prime \prime} \mathrm{S}\right.$ and $60^{\circ} 13^{\prime} 09.5^{\prime \prime} \mathrm{W}$ ) are reserved for subsistence fishing, in addition to the managed fishing of Arapaima sp. and other species, while always complying with the current legislation;

- Open fishing lakes: Lakes Caído $\left(03^{\circ} 17^{\prime} 35.1^{\prime \prime} \mathrm{S}\right.$ and $\left.60^{\circ} 12^{\prime} 35.0^{\prime \prime} \mathrm{W}\right)$ and Piranha $\left(03^{\circ} 17^{\prime} 57.3^{\prime \prime} \mathrm{S}\right.$ and $60^{\circ} 13^{\prime} 20.0^{\prime \prime} \mathrm{W}$ ) where commercial fishing is permitted when it complies with current legislation and where Arapaima sp. and other species may be farmed (Figure 1).

\section{Data Collection}

Fish assemblage samples were taken before and after the implementation of the Arapaima sp. management plan, always during the rising and receding water periods of the hydrological cycle. These two moments are when the water level is the same, but they occur before the connection among lakes that happens during the high water season (Supplementary Appendix I). A total of 48 sampling events were carried out, 24 before implementation of co-management (BM; in 2004, 2005, and 2006) and 24 after implementation of co-management (AM; in 2016 and 2017), a table with the sample design is available in Supplementary Appendix II to better understanding the sampling. The sampling was carried out with standardized fishing effort, using gill nets of $15 \mathrm{~m}$ in length $\times 2 \mathrm{~m}$ height, with mesh sizes ranging from $30,40,50,60,70,80,90,100,110$, and $120 \mathrm{~mm}$ between opposite knots, which establishes a battery of ten nets. Two batteries of nets were used, which were located near the shore and in the center of the lake, in order to sample species of the aquatic environment. The daily sampling period was of $8 \mathrm{~h}$, which was divided into $4 \mathrm{~h}$ in the early morning (04:00-08:00) and $4 \mathrm{~h}$ in the late afternoon (16:00-20:00), in order to reduce the damage caused by predators attracted to the fish in the nets and sample the hours of principal activity of the fish. These samples were grouped to use in analysis described in the next section.

The fish were identified with the help of systematic keys (Géry, 1977; Ferreira et al., 1998; Santos et al., 2006; Soares et al., 2007) and individual standard length $(\mathrm{cm})$ and total weight (g.) were measured. The specimens that were unable to be identified were preserved in 10\% formalin and taken to the Laboratory of Fisheries Ecology at the Federal University of Amazonas (UFAM) for subsequent identification with the help of specialized professionals. Fish sampling for this study was carried out under license No. 50662-1 (Instituto Chico Mendes de Conservação da Biodiversidade-ICMBio/Brazil). Along with fish samples, we measured the environmental parameters: temperature, $\mathrm{pH}$, and dissolved oxygen, depth and transparency levels at each lake, at the same spots where we set gillnets. We measured these environmental variables in the early morning and late afternoon, near to the water surface and bottom, and averaged these data in a single daily measure for each variable. The free software QGIS, version 2.8.5 (OSGEO, 2015) was used to measure the distance between the lakes shown in Figure 1.

\section{Data Analyses}

The composition and structure of the fish assemblages were described through estimates of richness (S), Shannon's diversity $\left(\mathrm{H}^{\prime}\right)$, numerical abundance $(\mathrm{N})$, and catch per unit of effort $\left(\right.$ CPUEn $=$ number of $f i s h / \mathrm{m}^{2} / \mathrm{h}$ and CPUEw $=$ weight of fish $/ \mathrm{m}^{2} / \mathrm{h}$ ). To test the effect of co-management time 


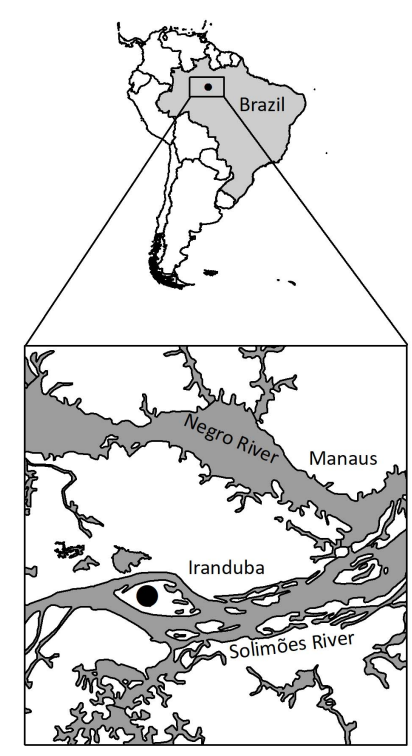

Source: INPE, IBGE

Datum: WGS 84

Satellite Imagery

LandSat 8 OLI, 2015

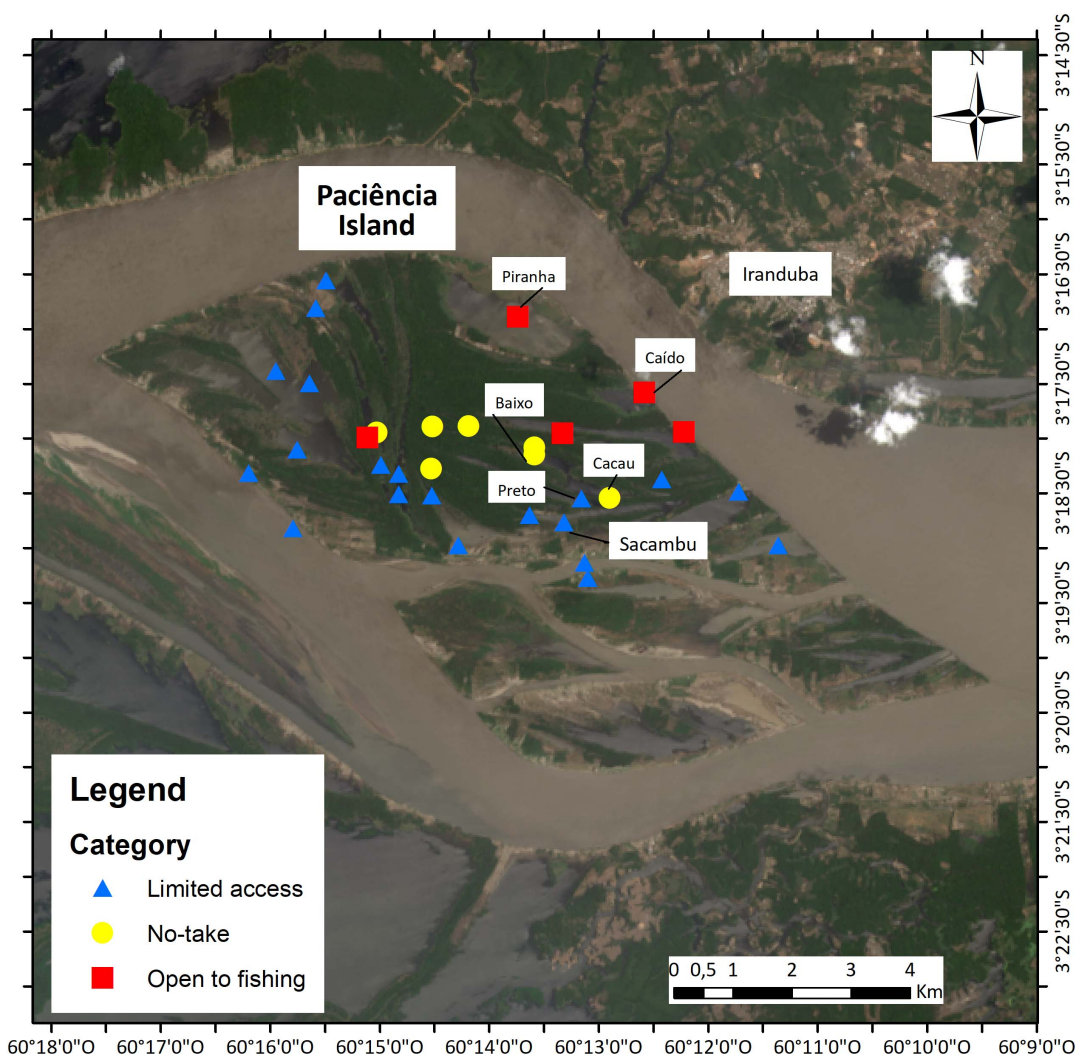

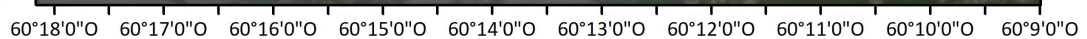

FIGURE 1 | Study area showing the sampling lakes per category of management regime on the Paciência Island (Amazon Basin, Brazil).

(before and after co-management) and among the categories of fishing restriction (No-take, limited access and open fishing) in the lakes on the diversity of fish assemblage and environmental parameters, we applied a two-way analysis of variance (ANOVAs), where the response variables were $S, H$, $\mathrm{N}$, capture per unit of effort (in number) (CPUEn), capture per unit of effort (in weight) (CPUEw), and environmental parameters (temperature, $\mathrm{pH}$, oxygen, depth, and transparency). Pearson's linear correlation was also applied to verify relationships among the structure of the fish assemblages and environmental parameters. Assumptions of normality, linearity, and homoscedasticity were inspected employing the residuals before running these ANOVAs and we log-transformed the data to ensure these assumptions were met.

To evaluate the existence of statistical differences in the species composition of fish assemblages, a two-way multivariate analysis of permutational variance was performed (PERMANOVA: factor 1 = management time; factor 2 = categories of fishing restriction). Beforehand, the numerical abundance data were transformed using the Hellinger distance, and a Bray-Curtis dissimilarity matrix (Anderson, 2008) was used as the basis for the PERMANOVA. Then, the percentage similarity routine (SIMPER) was applied to the Bray-Curtis dissimilarity matrix, identifying the species that most contributed to the formation of the groups, assuming $p \leq 0.05$ as the limit of significant contribution of each species. A non-metric dimensional scaling
(nMDS) (Borcard et al., 2018) was performed to show the patterns detected by PERMANOVA and SIMPER analysis. Differences in length composition for groups of species identified in SIMPER analysis, by co-management time was tested using a two-sample Kolmogorov-Smirnov test and among the categories of fishing restriction, we applied a Kruskal-Wallis test, both with a significance level of $p \leq 0.05$.

Finally, a Mantel test (Mantel, 1967) was used to test the effect of the distance between lakes on the fish assemblage and evaluate the existence of correlations among the ecological distances (alpha diversity) and the geographical distances between the lakes. This was assumed because the Euclidean distances were estimated from the numerical abundance data of the species in each lake. All statistical analyses were performed using the software R-4.0.1 (R Core Team, 2020), using the packages Vegan (Oksanen et al., 2007) and ggplot2 (Wickham, 2016).

\section{RESULTS}

\section{Fish Abundance and Species Composition}

A total of 7,647 fish were collected, corresponding to $547.19 \mathrm{~kg}$, which were distributed among 112 species, 24 families, and six orders (Supplementary Appendix III). Of this total, 2,105 fish with a biomass of $152.74 \mathrm{~kg}$ were collected before co-management 


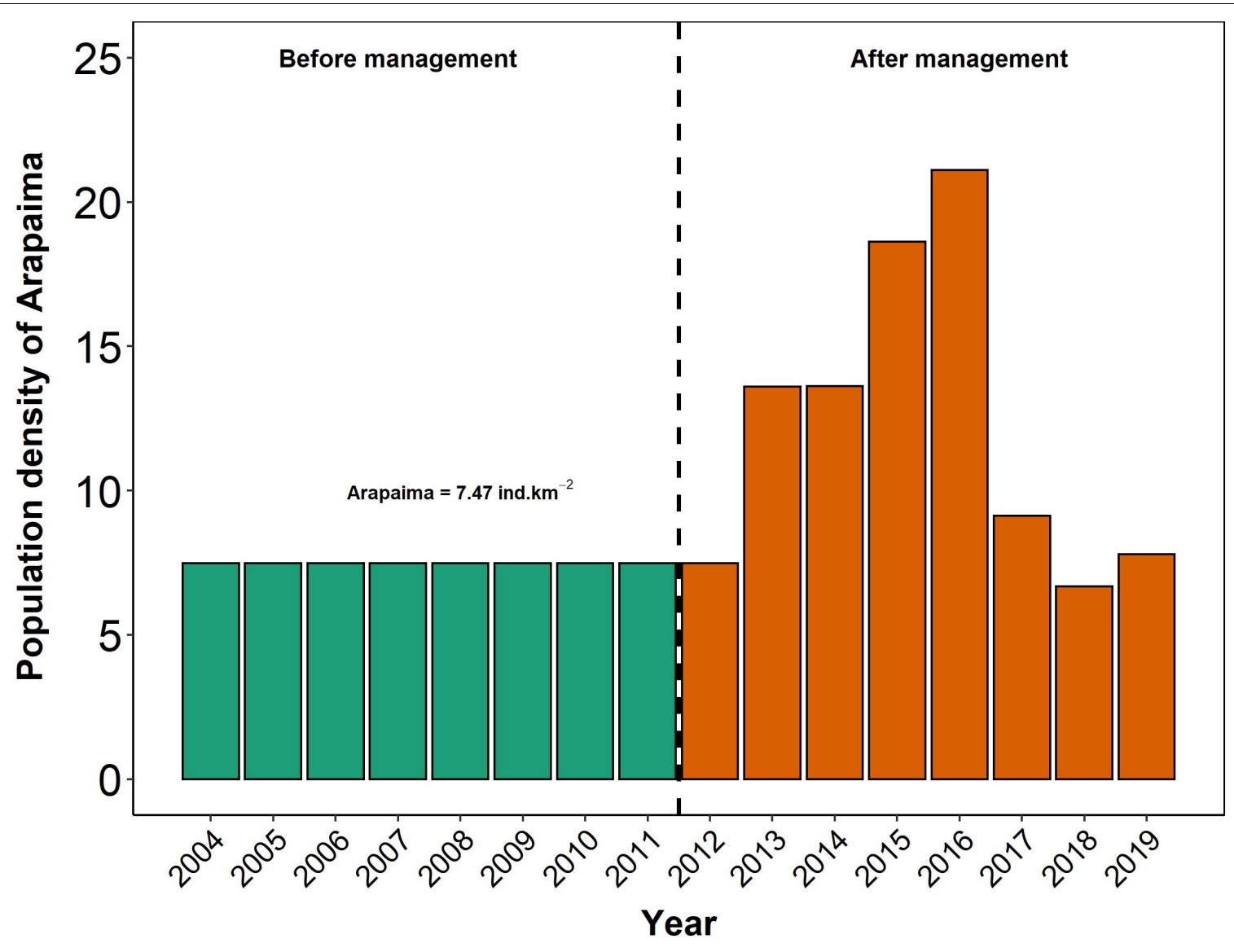

FIGURE 2 | Time-series data on population density of Arapaima sp. based by counts (>1 m total length) in Paciência Island. Density data shown for 2004-2011 are estimated based on the assumption that they are identical to that for 2012, first year with annual counts.

(BM), and were distributed in 78 species, 22 families, and six orders. After the co-management was implemented (AM), 5,542 fish with a biomass of $394.45 \mathrm{~kg}$ were caught, and these were distributed in 98 species, 24 families, and six orders.

Our findings reveal that the implementation of comanagement for Arapaima sp. affected the structure and composition of the fish assemblage. The two-way ANOVAs showed significant differences for numeric abundance $(F=27.42$; $\mathrm{df}=1,42 ; p<0.001)$, species richness $(F=9.24 ; \mathrm{df}=1,42$; $p=0.004)$, CPUEn $(F=27.42$; df $=1,42 ; p<0.001)$, and CPUEw $(F=18.486 ; \mathrm{df}=1,42 ; p<0.001)$ which indicates that the implementation of the co-management system resulted in greater abundance, biomass and diversity throughout the lake system of the Paciência Island (Figures 3A-E). We also found that the fish assemblage varied, not only with respect to the implementation of co-management, but also across floodplain lakes under different management regimes. The two-way ANOVAs indicated significant differences of numeric abundance $(F=4.36 ; \mathrm{df}=2,42 ; p=0.019)$, species richness $(F=4.67 ; \mathrm{df}=2$, $42 ; p=0.014)$, and CPUEn $(F=4.36 ; \mathrm{df}=2,42 ; p=0.019)$ among lakes under distinct management regimes. There were no detectable effects of co-management time among the categories of fishing restriction with Shannon's diversity index measured and no interaction effect was detected between the factors and all response variables: S, H', N, CPUEn, and CPUEw (Table 1). Lakes of limited access, where a quota of Arapaima sp. is fished annually, showed the highest values of numeric abundance, species richness, CPUEn, and CPUEw (Figures 3A,B,D,E).

The PERMANOVA identified differences in the structure of the assemblages sampled both before and after the implementation of the co-management (pseudo-F $=5.69$, $\left.\mathrm{df}=1.42, R^{2}=0.105, p=0.001\right)$, and indicated differences in the structure and composition of the assemblages of fish in the lakes, according to the categories of restriction on the fishery (pseudo-F $=1.96, \mathrm{df}=2.42, R^{2}=0.072$, $p<0.001)$. No interaction effect was detected between the factors of management implementation period and type of lake according to the level of fishing restriction (pseudo-F $=1.28, \mathrm{df}=2.42, R^{2}=0.047, p=0.122$ ). The nMDS (stress value: 0.212) helped to better explore the results of the PERMANOVA, which indicated a clear distinction between the assemblages sampled before (to the right), and after (to the left) the implementation of the comanagement scheme in the lake system of the Paciência Island. Brycon amazonicus (BRA), Psectrogaster rutiloides (PSR), and Mesonauta festivum (MFE) were the dominant 
TABLE 1 | Summary of results of two-way ANOVAs employing numerical abundance (N), catch per unit effort (CPUEn = number of fish/m2/h and CPUEw = weight of fish/m2/h), richness $(S)$ and Shannon's index ( $\left.H^{\prime}\right)$ as response variables.

\begin{tabular}{|c|c|c|c|c|c|c|c|c|c|c|c|}
\hline & \multirow[t]{2}{*}{ df } & \multicolumn{2}{|c|}{$\mathbf{N}$} & \multicolumn{2}{|c|}{ CPUEn } & \multicolumn{2}{|c|}{ CPUEw } & \multicolumn{2}{|c|}{$\mathbf{s}$} & \multicolumn{2}{|c|}{$H^{\prime}$} \\
\hline & & $\boldsymbol{F}$ & $p$ & $\boldsymbol{F}$ & $p$ & $\boldsymbol{F}$ & $p$ & $\boldsymbol{F}$ & $p$ & $\boldsymbol{F}$ & $p$ \\
\hline Time & 1 & 27.429 & $<0.001$ & 27.429 & $<0.001$ & 18.486 & $<0.001$ & 9.24 & 0.004 & 0.237 & 0.629 \\
\hline Categories & 2 & 4.251 & 0.019 & 4.251 & 0.019 & 2.467 & 0.097 & 4.676 & 0.014 & 2.765 & 0.074 \\
\hline Time $\times$ Categories & 2 & 2.513 & 0.093 & 2.513 & 0.093 & 0.919 & 0.406 & 1.828 & 0.173 & 1.302 & 0.282 \\
\hline Residuals & 42 & & & & & & & & & & \\
\hline
\end{tabular}

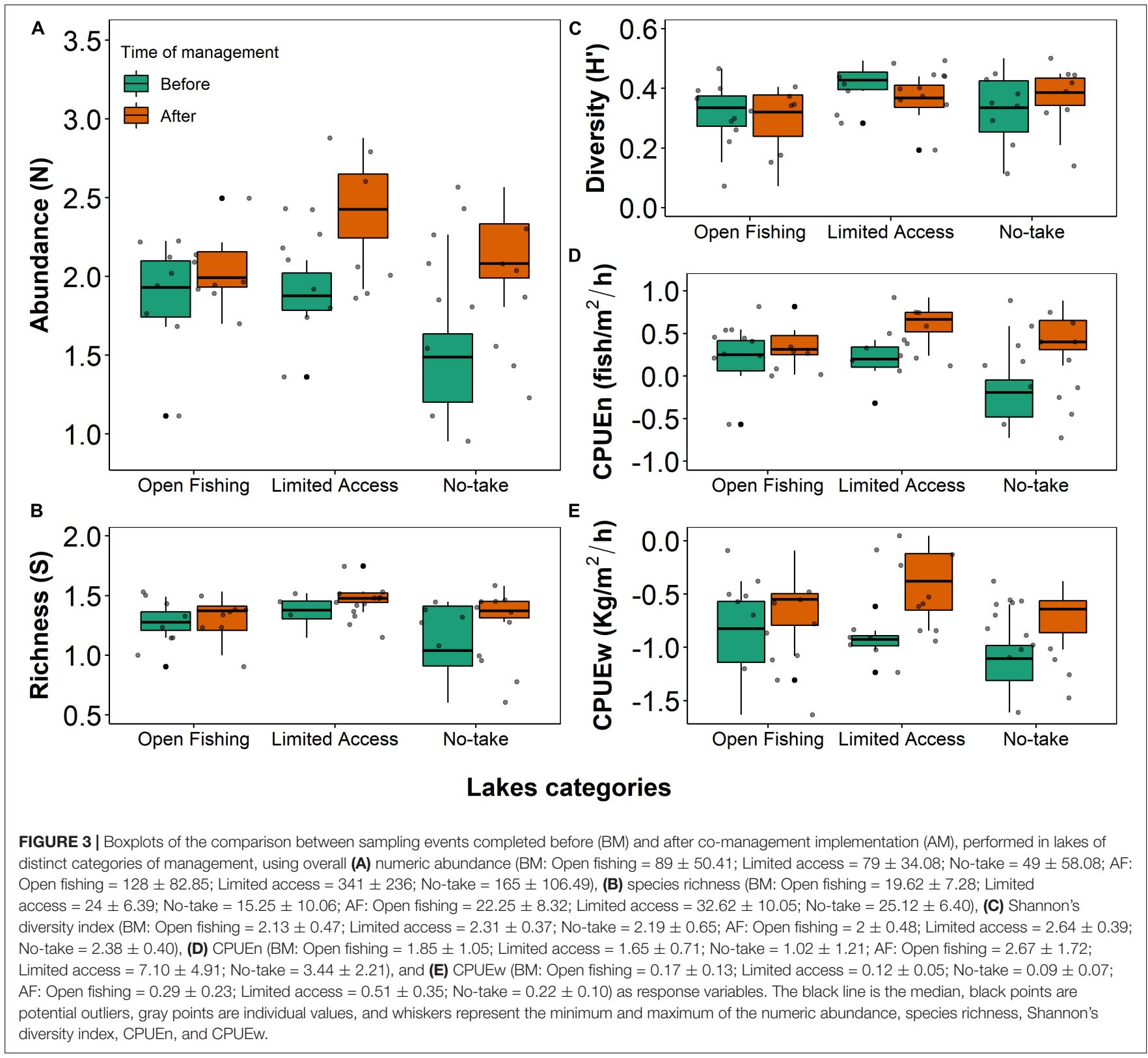

species in the assemblages before the implementation of co-management, however Ageneiosus ucayalensis (AGU), Triportheus albus (TRA), Tetragnopterus argenteus (TAR), Calophysus macropterus (CMA), and Curimata ocellata (COC) dominated the assemblages after the implementation of co-management (Figure 4).

The SIMPER analysis identified eleven fish species that contributed most to the observed differences among the 


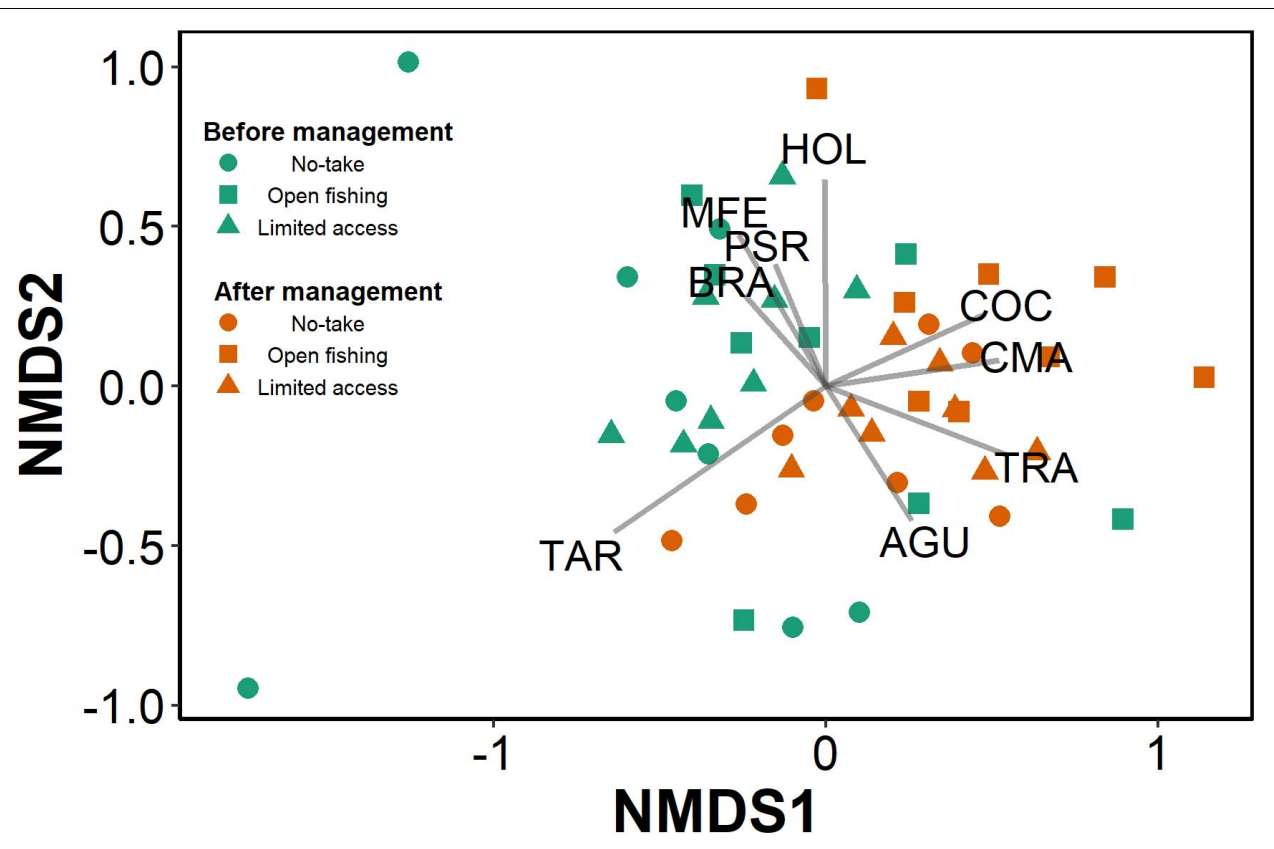

FIGURE 4 | Non-metric multidimensional scaling (axes nMDS1 vs. nMDS2) plot where the green points represent the sampling events completed performed before co-management implementation and orange represent the sampling events completed after co-management implementation. Circles represent samplings in no-take lakes, triangles represent samplings in limited access lakes, and squares in open to fishing lakes. BRA, Brycon amazonicus; PSR, Psectrogaster rutiloides; MFE, Mesonauta festivum; AGU, Ageneiosus ucayalensis; TRA, Triportheus albus; TAR, Tetragnopterus argenteus; CMA, Calophysus macropterus; COC, Curimata ocellata.

co-management time and categories of fishing restriction: Potamorhina altamazonica (PAL) was more abundant in open fishing and limited access and Triportheus angulatus (TAN) in no-take lakes before the co-management (Figures $5 \mathrm{~A}-\mathrm{C}$ ). After co-management, TRA and TAN were more abundant in three categories (Figures 5D-F). The lengths of these species were different over time (Kolmogorov-Smirnov: $D=0.138$; $p<0.001$; Figure 6A) and among the categories of fishing restriction (Kruskal-Wallis: $x^{2}=51.16 ; p<0.001$ ), showing a subtle increase in fish sizes after the implementation of comanagement (Figure 6B).

\section{Environmental Variables}

The means values of temperature $\left({ }^{\circ} \mathrm{C} ; F=5.51\right.$; $\mathrm{df}=1,42$; $p=0.02), \mathrm{pH}(F=35.42 ; \mathrm{df}=1,42 ; p<0.001)$, and dissolved oxygen (mg. $1^{-1} ; F=8.02 ; \mathrm{df}=1,36 ; p=0.03$ ), differ over time (before and after co-management). Transparency $(\mathrm{cm} ; F=6.07$; $\mathrm{df}=2,27 ; p<0.003)$ differed only according to the categories of restriction on fishing. The environmental parameters dissolved oxygen, temperature, and $\mathrm{pH}$ did not differ between lakes categories or depth. Considering all sampling events (total 48), only $\mathrm{pH}$ showed a correlation to numeric abundance $\left(R^{2}=0.38\right.$; $\mathrm{df}=46 ; p=0.008)$, CPUEn $\left(R^{2}=0.37 ; \mathrm{df}=46 ; p=0.008\right)$, CPUEw $\left(R^{2}=0.37 ; \mathrm{df}=46 ; p=0.009\right)$, and species richness $\left(R^{2}=0.37\right.$; $\mathrm{df}=46 ; p<0.009)$. All mean and standard deviations values of these environmental parameters are presented in Table 2.

The Mantel test indicated a low correlation $\left(R^{2}=0.227\right.$; $p=0.177)$ among the ecological distances and the geographical distances among the lakes, indicating that the differences observed among the assemblage estimates obtained in the lakes, according to the type of co-management, are not related to the geographical distances among the lakes.

\section{DISCUSSION}

Our results indicate that co-management focused on one single taxa and implemented within a framework of zoning of fishing activities improved the structure and composition of the fish assemblages in floodplain lakes of the Amazon Basin. Several new fish species were sampled in the Paciência Island after the co-management was implemented, such as Acestrorhynchus falcatus, Sternarchella schotti, Parapteronotus hasemani, Pristigaster cayana, Hemiodus unimaculatus, Metynnis hypsauchen, etc., and two new families: Apteronotidae and Sternopygidae. Our results show that the implementation of Arapaima sp. co-management induced beneficial changes for the fish assemblages of the lakes of the Paciência Island, with increases in the abundance (Numerical and CPUEn), biomass (CPUEw), size $\left(S_{L}, \mathrm{~cm}\right)$, and richness of species. These increases in biodiversity provide greater buffering effects against disturbances, helping to ensure ecosystem stability (McCann, 2000; Nagelkerken et al., 2017). Similarly, previous studies have shown that areas under some type of management have higher values of species richness when compared to areas open to fishing and without management (Lubchenco et al., 2003; Sweke et al., 2013). The greatest increases in total abundance, when summed across all lakes, after the implementation of the fishing agreement were observed in small species, such as TRA, TAN, Potamorhina latior, and PAL, medium size species, such as Mylossoma 


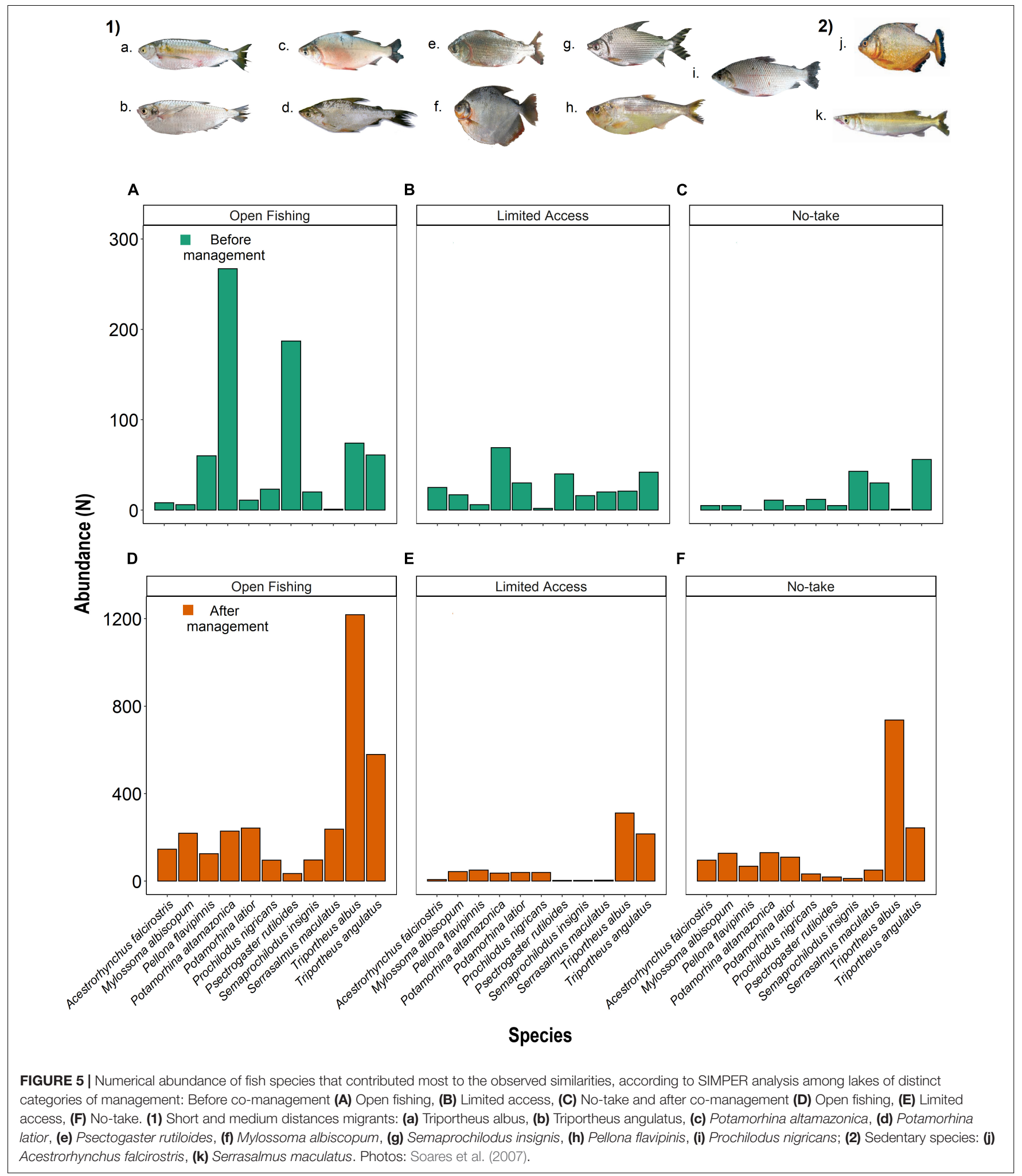

albiscopum, Semaprochilodus insignis, and Prochilodus nigricans, and larger sized species, such as Pellona flavipinnis, which are typical shoal-forming and short- and medium-distance migrants (Figures 5D-F; Taphorn, 1992; Villacorta-Correa and Saint-Paul,
1999; Lima and Araujo-Lima, 2004; Malabarba, 2004; GranadoLorencio et al., 2005). Some medium and large sedentary species (Neves, 2000; Ruffino and Issac, 2000; Granado-Lorencio et al., 2005) also showed an increase in abundance, such as Serrasalmus 

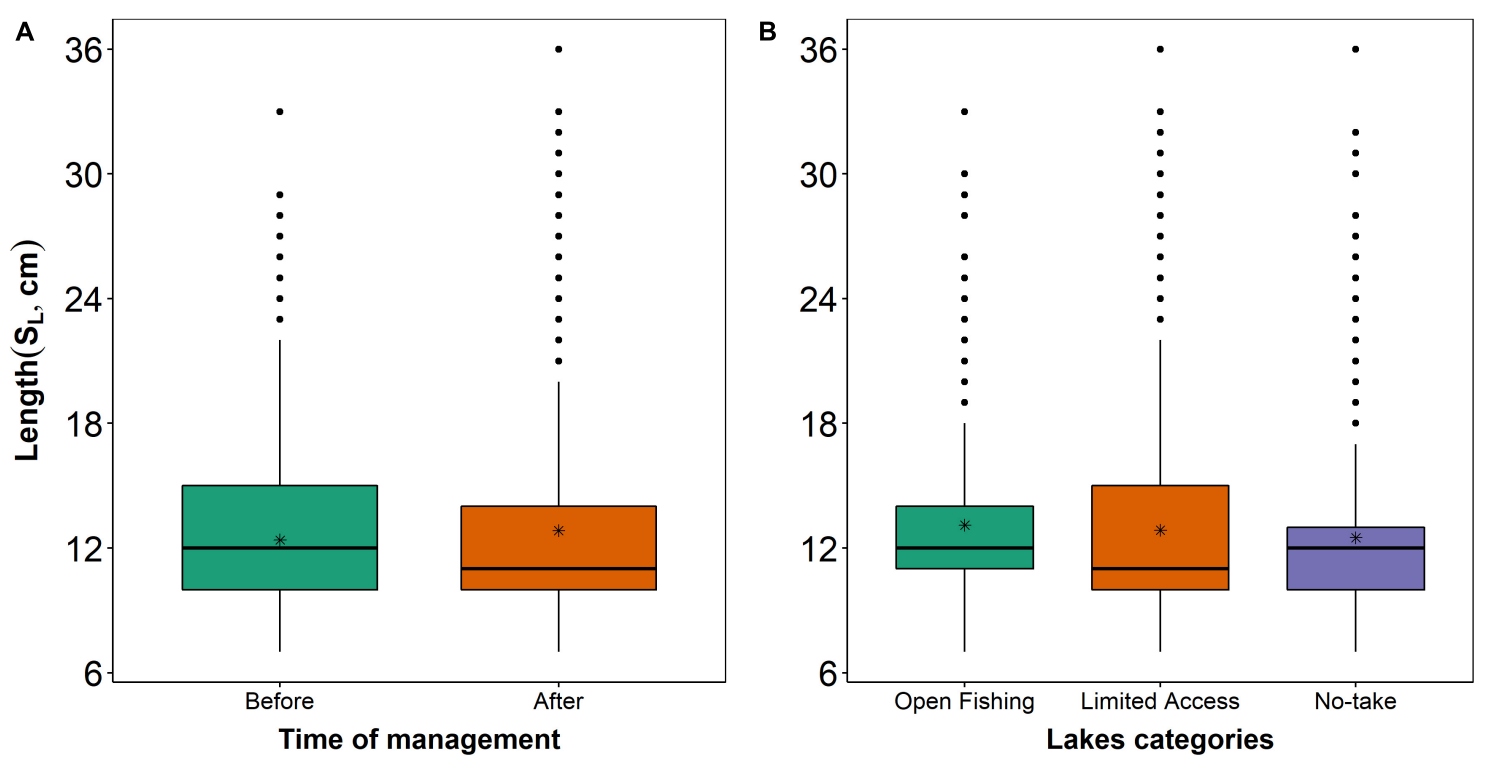

FIGURE 6 | Boxplots of the standard length $\left(S_{L}, \mathrm{~cm}\right)$ of 11 fish species identified by SIMPER analysis, compared between (A) sampling events completed before (BM) and after co-management implementation (AM) and performed in lakes of distinct categories of management (B). The black line is the median, black points are potential outliers, asterisks are the average of standard length, and whiskers represent the minimum and maximum of the standard length.

maculatus and Acestrorhynchus falcirostris (Figures 5D-F). In the Paciência Island, most of these species have a commercial importance for local fishers (Souza et al., 2015). A similar pattern also was observed in floodplain lakes with co-managed measures in the eastern Amazon for some species, such as P. nigricans and A. falcirostris (Silvano et al., 2014).

The positive effects of the co-management, evidenced by the comparison between sampling done before and after the implementation of the fishing agreement for the Paciência Island lakes, could be due the homogenization process promoted annually by the flooding. The flooding season creates connections between the floodplain habitats (lakes and rivers), allowing fish to move and migrate between habitats, resulting in a homogenization of fish communities (Freitas et al., 2010; Gomes et al., 2012; Hurd et al., 2016). The homogenization that occurs in the flood, when there is an expansion of aquatic environments, can also minimize the effects of biotic interactions (Gomes et al., 2012), including the potential increase in predation levels that result from the increase in population density of Arapaima sp. (Figure 2).

The results also indicated that the effects are distinct among lakes with distinct levels of fishing restriction, with higher abundances both in number of individuals, CPUEn, biomass (CPUEw), richness, and sizes $\left(S_{L}, \mathrm{~cm}\right)$ in limited access lakes. The effects of predation on the structures of aquatic communities have been observed in several types of aquatic environments, including small lakes (Tonn et al., 1992), streams in temperate environments (Giam and Olden, 2016), coral reefs (Boaden and Kingsford, 2015), and floodplain lakes (Rodríguez and Lewis, 1997), without intervention of management actions. In addition, in most freshwater tropical environments, predation is a driving force in fish community structure, affecting the species composition, abundance, biomass, and can mediate species coexistence in the short term (Freitas et al., 2010; Petry et al., 2010). Our results indicate that managed fishing in these lakes, with the annual harvesting of a pre-established number of Arapaima sp. (one of the top predators in the food chain) presents the most positive effects for the fish assemblages of the Amazon floodplain lakes. This annual harvesting of part of the predators can modulate the top down effects that act in the structuring of fish assemblages (Borer et al., 2005).

Similar studies, previously conducted by Silvano et al. (2009); Soares et al. (2014), and Morales et al. (2019), in different managed areas of the Brazilian Amazon, did not observe differences in the composition and structure of fish assemblages among lakes of different categories of fishing restrictions. According to these studies, the absence or non-detection of the effects of the type of management can be explained by factors such as the distance from the lakes to the river, short periods of effective management, and the existence of high intensity ecological factors, such as the flood pulse, which overlaps with the lower intensity effects that result from management. Our study provides new insights into co-management effects in freshwater ecosystems, as we compare data collected over an interval of more than 10 years (before and after-co-management), which may have allowed us to demonstrate the consolidation of the effects of management and potential spillover effects. Such a process can be defined as the net movement of fish across the boundary of a reserve into the fished ground, which would be expected to occur on the basis of fundamental physical principles of random movement (Buxton et al., 2014). The spillover effect provides an increase in fishing yields, abundance, and biomass, as well as helping to protect biodiversity in environments near to no-take zones (Russ et al., 2004). This effect has been observed mainly in marine protected areas (MPAs) (Buxton et al., 2014), communitymanaged marine reserves (Silva et al., 2015) and also suggested 
TABLE 2 | The mean (with standard deviation values) of the environmental variables of Paciência Island in the lower Solimões River.

\begin{tabular}{|c|c|c|c|c|c|c|}
\hline \multirow[b]{2}{*}{ Environmental variables } & \multicolumn{3}{|c|}{ Before management (BM) } & \multicolumn{3}{|c|}{ After management (AM) } \\
\hline & Open to Fishing & Limited Access & No-take Zones & Open to Fishing & Limited Access & No-take Zones \\
\hline Dissolved oxygen & $2.49 \pm 1.48$ & $3.41 \pm 1.36$ & $2.64 \pm 1.32$ & $1.8 \pm 1.43$ & $2.26 \pm 1.14$ & $1.14 \pm 0.52$ \\
\hline $\mathrm{pH}$ & $6.82 \pm 0.49$ & $6.91 \pm 0.43$ & $6.82 \pm 0.26$ & $7.56 \pm 0.34$ & $7.63 \pm 0.28$ & $7.83 \pm 0.80$ \\
\hline Temperature $\left({ }^{\circ} \mathrm{C}\right)$ & $30.09 \pm 1.83$ & $30.55 \pm 2.21$ & $30.64 \pm 0.26$ & $29.25 \pm 0.89$ & $29.55 \pm 1.66$ & $27.92 \pm 3.41$ \\
\hline Depth (m) & $4.20 \pm 1.61$ & $4.08 \pm 6.39$ & $4.73 \pm 1.72$ & $4.21 \pm 3.37$ & $4.42 \pm 2.33$ & $3.2 \pm 2.58$ \\
\hline Transparency (cm) & $59 \pm 15.14$ & $71.83 \pm 8.18$ & $87.83 \pm 31.65$ & $58.33 \pm 16.93$ & $76.5 \pm 23.21$ & $95 \pm 27.01$ \\
\hline
\end{tabular}

in floodplain lakes in the Amazon (Silvano et al., 2009; Arantes and Freitas, 2016). However, more ecosystem-based approaches should be considered using food-web models, assessing the ability of fisheries agreements to reduce fishing effort and to supply biomass to a near no-take zone.

It is known there are a complex relationship between environmental variables and fish assemblages in the Amazon (Rodríguez and Lewis, 1997; Tejerina-Garro et al., 1998; Petry et al., 2003; Keppeler et al., 2017). Most environmental parameters measured in our study showed significant differences before and after co-management implementation, but did not differ according to the categories of fishing restriction (except transparency). Furthermore, just $\mathrm{pH}$ was found to have a positive correlation with the fish assemblage descriptors. Floodplain lakes in the Amazon are dynamic environments and the environmental parameters change along a hydrological cycle (rising, high, receding, and dry waters, see Supplementary Appendix I). However, we believe the effects of the co-management to be more important than the effects of the environmental variables, which can experience natural variations. Previous studies have also shown that piscivory is one of the factors driving the structure of fish assemblages in tropical floodplain lakes (Rodríguez and Lewis, 1997). Piscivory is influenced by transparency, which is controlled by depth and area, and which emphasizes the random contribution to assemblage variation in these environments (Rodríguez and Lewis, 1997; Freitas et al., 2014). All of the lakes sampled in this study are in the lower stretch of the Solimões River, one of the largest white water rivers in the Amazon, and the differences in $\mathrm{pH}$, oxygen, and temperature can be random. Therefore, we need to better understand how environmental variables do influence fish assemblage in tropical rivers, so that they can be accounted for in management proposals for fish conservation and fisheries sustainability (Keppeler et al., 2017).

Although it is not the primary objective of this article, it is important to mention the social and economic benefits of fishing agreements that have been implemented in the Amazonian floodplains, and which have been proven by several studies (Castello et al., 2009, 2011; Campos-Silva and Peres, 2016; Campos-Silva et al., 2017). In the system of lakes of the Paciência Island, in addition to the increments in the income of the riverine population, as a result of the annual fishing of Arapaima sp., it was observed an increase of the abundance of other species, which can contribute to food security of the riverine people who fish for subsistence in these lakes.

\section{CONCLUSION}

The co-management strategy known as the Fisheries Agreement, which is implemented in the floodplain lakes of the Paciência Island, although aimed at the recovery of stocks and the maintenance of sustainable fishing of Arapaima sp. had positive effects on the entire fish assemblage, with increases in abundance, biomass, richness, and sizes. The results also indicate that managed fishing of this species (a top predator in the food chain of the Amazonian floodplains) may be contributing to the maintenance of the abundance and diversity of the lakes where fishing restricted by annual quotas occurs. The continuity and improvement of this fishery management strategy will depend directly on the expansion of knowledge of the biology of the species exploited, the environmental characteristics of the lakes where they live and the biological interactions in the assemblage.

\section{DATA AVAILABILITY STATEMENT}

The original contributions presented in the study are included in the article/Supplementary Material, further inquiries can be directed to the corresponding author/s.

\section{ETHICS STATEMENT}

The animal study was reviewed and approved by License No. 50662-1 153 (Instituto Chico Mendes de Conservação da Biodiversidade-ICMBio/Brazil).

\section{AUTHOR CONTRIBUTIONS}

FS-S and WM-L designed the study. WM-L performed the sampling, collected the data, and analyzed and drafted the original version of the manuscript. LC and CF reviewed the manuscript. FS-S supervised this research, obtained financial support, and discussed and revised the manuscript. All authors contributed to the article and approved the submitted version.

\section{FUNDING}

WM-L received a post-graduate grant from CAPES (Finance Code 001). Financial support for LC during manuscript 
preparation was provided by the US National Science Foundation (NSF ICER Belmont Forum \#1852113). Amazonas State Research Foundation (FAPEAM PAPAC 005/2019-962.00847.2019). The CNPq and INCT ADAPTA support the sampling and field work.

\section{ACKNOWLEDGMENTS}

To the fishers of the fishing agreement of the Paciência Island, Iranduba, Amazonas State, Brazil for allowing the realization of

\section{REFERENCES}

Almeida, O. T., Lorenzen, K., and McGrath, D. G. (2009). Fishing agreements in the lower Amazon: for gain and restraint. Fish. Manag. Ecol. 16, 61-67. doi: 10.1111/j.1365-2400.2008.00647.x

Anderson, M. J. (2008). Animal-sediment relationships re-visited: characterizing species' distributions along an environmental gradient using canonical analysis and quantile regression splines. J. Exp. Mar. Biol. 366, 16-27.

Andrew, N. L., Béné, C., Hall, S. J., Allison, E. H., Heck, S., and Ratner, B. D. (2007). Diagnosis and management of small-scale fisheries in developing countries. Fish Fish. 8, 227-240. doi: 10.1111/j.1467-2679.2007.00252.x

Arantes, C. C., Winemiller, K. O., Asher, A., Castello, L., Hess, L. L., and Petrere, M. (2019). Floodplain land cover affects biomass distribution of fish functional diversity in the Amazon River. Sci. Rep. 9:16684. doi: 10.1038/s41598-01952243-0

Arantes, M. L., and Freitas, C. E. C. (2016). Effects of fisheries zoning and environmental characteristics on population parameters of the tambaqui (Colossoma macropomum) in managed floodplain lakes in the Central Amazon. Fish. Manag. Ecol. 23, 133-143. doi: 10.1111/fme.12164

Azevedo-Santos, V. M., Frederico, R. G., Fagundes, C. K., Pompeu, P. S., Pelicice, F. M., and Padial, A. A. (2019). Protected areas: a focus on Brazilian freshwater biodiversity. Divers. Distrib. 25, 442-448. doi: 10.1111/ddi.12871

Batista, V. S., Inhamuns, A. J., Freitas, C. D. C., and Freire-Brasil, D. (1998). Characterization of the fishery in river communities in the low-Solimões/highamazon region. Fish. Manag. Ecol. 5, 419-435. doi: 10.1046/j.1365-2400.1998. 550419.x

Baum, J. K., and Worm, B. (2009). Cascading top-down effects of changing oceanic predator abundances. J. Anim. Ecol. 78, 699-714. doi: 10.1111/j.1365-2656. 2009.01531.x

Bellwood, D. R., Hoey, A. S., and Choat, J. H. (2003). Limited functional redundancy in high diversity systems: resilience and ecosystem function on coral reefs. Ecol. Lett. 6, 281-285. doi: 10.1046/j.1461-0248.2003.00432.x

Berkes, F. (2009). Evolution of co-management: role of knowledge generation, bridging organizations and social learning. J. Environ. Manage. 90, 1692-1702. doi: 10.1016/j.jenvman.2008.12.001

Boaden, A. E., and Kingsford, M. J. (2015). Predators drive community structure in coral reef fish assemblages. Ecosphere 6, 1-33. doi: 10.1890/ES14-00292.1

Borcard, D., Gillet, F., and Legendre, P. (2018). Numerical Ecology with R. Cham: Springer.

Borer, E. T., Seabloom, E. W., Shurin, J. B., Anderson, K. E., Blanchette, C. A., and Broitman, B. (2005). What determines the strength of a trophic cascade? Ecology 86, 528-537. doi: 10.1890/03-0816

Buxton, C. D., Hartmann, K., Kearney, R., and Gardner, C. (2014). When is spillover from marine reserves likely to benefit fisheries? PLoS One 9:e107032. doi: 10.1371/journal.pone.0107032

Campos, C. P., Costa Sousa, R. G., Catarino, M. F., de Albuquerque Costa, G., and Freitas, C. E. C. (2015). Population dynamics and stock assessment of Colossoma macropomum caught in the Manacapuru Lake system (Amazon Basin, Brazil). Fish. Manag. Ecol. 22, 400-406. doi: 10.1111/fme. 12139

Campos-Silva, J. V., Hawes, J. E., Andrade, P. C. M., and Peres, C. A. (2018). Unintended multispecies co-benefits of an Amazonian community-based conservation programme. Nat. Sustain. 1, 650-656. doi: 10.1038/s41893-0180170-5 this study. Amazonas State Research Foundation publication of scientific articles support program (PAPAC).

\section{SUPPLEMENTARY MATERIAL}

The Supplementary Material for this article can be found online at: https://www.frontiersin.org/articles/10.3389/fevo.2021. 604170/full\#supplementary-material

Campos-Silva, J. V., and Peres, C. A. (2016). Community-based management induces rapid recovery of a high-value tropical freshwater fishery. Sci. Rep. 6:34745.

Campos-Silva, J. V., Peres, C. A., Antunes, A. P., Valsecchi, J., and Pezzuti, J. (2017). Community-based population recovery of overexploited Amazonian wildlife. Perspect. Ecol. Conserv. 15, 266-270. doi: 10.1038/srep34745

Carlsson, L., and Berkes, F. (2005). Co-management: concepts and methodological implications. J. Environ. Manage. 75, 65-76. doi: 10.1016/j.jenvman.2004.11. 008

Castejón, M., and Charles, A. (2013). Improving fisheries co-management through ecosystem-based spatial management: the Galapagos marine reserve. Mar. Policy 38, 235-245. doi: 10.1016/j.marpol.2012.05.040

Castello, L. (2004). A method to count pirarucu Arapaima gigas: fishers, assessment, and management. N. Am. J. Fish. Manag. 24, 379-389. doi: 10.1577/ M02-024.1

Castello, L., Viana, J. P., and Pinedo-Vasquez, M. (2011). "Participatory conservation and local knowledge in the Amazon várzea: the pirarucu management scheme in Mamirauá," in The Amazon Várzea, eds M. PinedoVasquez, M. Ruffino, C. Padoch, and E. Brondízio, (Dordrecht: Springer), 259-273.

Castello, L., Viana, J. P., Watkins, G., Pinedo-Vasquez, M., and Luzadis, V. A. (2009). Lessons from integrating fishers of Arapaima in small-scale fisheries management at the Mamirauá Reserve, Amazon. Environ. Manage. 43, $197-$ 209. doi: 10.1007/s00267-008-9220-5

Castro, F. (2000). Fishing Accords: The Political Ecology of Fishing Intensification in the Amazon. Ph.D. Dissertation, Indiana University, Bloomington, IN.

Chuenpagdee, R., and Jentoft, S. (2007). Step zero for fisheries co-management: what precedes implementation. Sci. Direct 31, 657-668. doi: 10.1016/j.marpol. 2007.03.013

Ferreira, E. J. G., Zuanon, J. A., and dos Santos, G. M. (1998). Peixes comerciais do médio Amazonas: região de Santarém, Pará. Brasília: Edições IBAMA, 211.

Freitas, C. E., Siqueira-Souza, F. K., Florentino, A. C., and Hurd, L. E. (2014). The importance of spatial scales to analysis of fish diversity in Amazonian floodplain lakes and implications for conservation. Ecol. Freshw. Fish. 23, 470-477. doi: 10.1111/eff.12099

Freitas, C. E. C., Laurenson, L., Yamamoto, K. C., Forsberg, B. R., Petrere, M. Jr., and Arantes, C. (2018). Fish species richness is associated with the availability of landscape components across seasons in the Amazonian floodplain. PeerJ 6:e5080. doi: $10.7717 /$ peerj.5080

Freitas, C. E. D. C., Siqueira-Souza, F. K., Guimarães, A. R., Santos, F. A., and Santos, I. L. (2010). Interconnectedness during high water maintains similarity in fish assemblages of island floodplain lakes in the Amazonian Basin. Zoologia (Curitiba) 27, 931-938. doi: 10.1590/S1984-46702010000600014

Gasparini, J. L., Floeter, S. R., Ferreira, C. E. L., and Sazima, I. (2005). Marine ornamental trade in Brazil. Biodivers. Conserv. 14, 2883-2899. doi: 10.1007/ s10531-004-0222-1

Gelcich, S., Godoy, N., Prado, L., and Castilla, J. C. (2008). Add-on conservation benefits of marine territorial user rights fishery policies in central Chile. Ecol. Appl. 18, 273-281. doi: 10.1890/06-1896.1

Gerber, L. R., Heppell, S. S., Ballantyne, F., and Sala, E. (2005). The role of dispersal and demography in determining the efficacy of marine reserves. Can. J. Fish. Aquat. Sci. 62, 863-871. doi: 10.1139/f05-046

Géry, J. (1977). Characoids of the World. Neptune: TFH Publications, 672. 
Giam, X., and Olden, J. D. (2016). Environment and predation govern fish community assembly in temperate streams. Glob. Ecol. Biogeogr. 25, 1194-1205. doi: 10.1111 /geb. 12475

Gomes, L. C., Bulla, C. K., Agostinho, A. A., Vasconcelos, L. P., and Miranda, L. E. (2012). Fish assemblage dynamic in a neotropical floodplain relative to aquatic macrophytes and the homogenizing effect of a flood pulse. Hydrobiologia 685, 97-107. doi: 10.1007/s10750-011-0870-6

Granado-Lorencio, C., Araújo-Lima, C. A. R. M., and Lobón- Cerviá, J. (2005). Abundance - distribuition relationships in fish assembly of the Amazonas floodplain lakes. Ecography 28, 515-520. doi: 10.1111/j.0906-7590.2005.04176. $\mathrm{x}$

Hallwass, G., Schiavetti, A., and Silvano, R. A. M. (2020). Fishers' knowledge indicates temporal changes in composition and abundance of fishing resources in Amazon protected areas. Anim. Conserv. 23, 36-47.

Hallwass, G., and Silvano, R. A. (2016). Patterns of selectiveness in the Amazonian freshwater fisheries: implications for management. J. Environ. Manage. 59, 1537-1559. doi: 10.1080/09640568.2015.1081587

Hurd, L. E., Sousa, R. G., Siqueira-Souza, F. K., Cooper, G. J., Kahn, J. R., and Freitas, C. E. (2016). Amazon floodplain fish communities: habitat connectivity and conservation in a rapidly deteriorating environment. Biol. Conserv. 195, 118-127. doi: 10.1016/j.biocon.2016.01.005

Isaac, V. J., Castello, L., Santos, P. R. B., and Ruffino, M. L. (2016). Seasonal and interannual dynamics of river-floodplain multispecies fisheries in relation to flood pulses in the Lower Amazon. Fish. Res. 183, 352-359. doi: 10.1016/j. fishres.2016.06.017

Keppeler, F. W., Hallwass, G., and Silvano, R. A. M. (2017). Influence of protected areas on fish assemblages and fisheries in a large tropical river. Oryx 51, 268-279. doi: 10.1017/S0030605316000247

Lima, A. C., and Araujo-Lima, C. A. R. M. (2004). The distributions of larval and juvenile fishes in Amazonian rivers of different nutrient status. Freshw. Biol. 49, 787-800. doi: 10.1111/j.1365-2427.2004.01228.x

Linke, S., and Bruckmeier, K. (2015). Co-management in fisheries-experiences and changing approaches in Europe. Ocean Coast. Manag. 104, 170-181. doi: 10.1016/j.ocecoaman.2014.11.017

Lorenzen, K., Cowx, I. G., Entsua-Mensah, R. E. M., Lester, N. P., Koehn, J. D., and Randal, R. G. (2016). Stock assessment in inland fisheries: a foundation for sustainable use and conservation. Rev. Fish Biol. Fish. 26, 405-440. doi: 10.1007/s11160-016-9435-0

Lubchenco, J., Palumbi, S. R., Gaines, S. D., and Andelman, S. (2003). Plugging a hole in the ocean: the emerging science of marine reserves. Ecol. Appl. 13, S3-S7. doi: $10.2307 / 3099993$

Mahon, R. (1997). Does fisheries science serve the needs of managers of small stocks in developing countries. Can. J. Fish. Aquat. Sci. 54, 2207-2213. doi: 10.1139/f97-112

Malabarba, M. C. S. L. (2004). Revision of the Neotropical genus Triportheus cope, 1872 (Characiformes: Characidae). Neotrop. Ichthyol. 2, 167-204. doi: 10.1590/S1679-62252004000400001

Mantel, N. (1967) The detection of disease clustering and a generalized regression approach. Cancer Res. 27, 209-220.

McCann, K. (2000). The diversity-stability debate. Nature 405, 228-233. doi: 10. $1038 / 35012234$

McClanahan, T. R., and Mangi, S. C. (2004). Gear-based management of a tropical artisanal fishery based on species selectivity and capture size. Fish. Manag. Ecol. 11, 51-60. doi: 10.1371/journal.pone.0036022

Medeiros-Leal, W. M., Freitas, C. E. C., and Siqueira-Souza, F. K. (2018). Diversidade de peixes em lagos manejados em área de várzea Amazônica brasileira. Sci. Amazon. 7, 1-10.

Morales, B. F., Ota, R. P., Silva, V. D. P., and Deus, C. P. D. (2019). Ichthyofauna from floodplain lakes of Reserva de Desenvolvimento Sustentável PiagaçuPurus (RDS-PP), lower rio Purus. Biota Neotrop. 19, 1-13. doi: 10.1590/16760611-BN-2019-0779

Nagelkerken, I., Goldenberg, S. U., Ferreira, C. M., Russell, B. D., and Connell, S. D. (2017). Species interactions drive fish biodiversity loss in a high-CO2 world. Curr. Biol. 27, 2177-2184. doi: 10.1016/j.cub.2017. 06.023

Neves, A. M. B. (2000). "Conhecimento atual sobre o pirarucu, Arapaima gigas," in Recursos Pesqueiros do médio Amazonas: Biologia e Estatística Pesqueira
(Coleção Meio Ambiente, Série Estudos Pesca, 22), ed. C. F. A. Fisher, (Brasília: Ediçôes IBAMA), 89-113.

Oksanen, J., Kindt, R., Legendre, P., O’Hara, B., Stevens, M. H. H., Oksanen, M. J., et al. (2007). The Vegan Package: Community Ecology Package 10:719.

Open Source Geospatial Foundation (OSGEO). (2015). QGIS Geographic Information System, Version 2.8.5, Massachusetts. Available online at: http: //qgis.osgeo.org

Pauly, D., and Christensen, V. (1993). "Stratified models of large marine ecosystems: a general approach, and an application to the South China Sea, in Stress, Mitigation and Sustainability of Large Marine Ecosystems, eds K. Sherman, L. M. Alexander, and B. D. Gold, (Washington, D.C: American Association for the Advancement of Science), 148-174.

Petersen, T. A., Brum, S. M., Rossoni, F., Silveira, G. F. V., and Castello, L. (2016). Recovery of Arapaima sp. populations by community-based management in floodplains of the Purus River. Amazon. J. Fish. Biol. 89, 241-248. doi: 10.1111/ jfb. 12968

Petry, A. C., Gomes, L. C., Piana, P. A., and Agostinho, A. A. (2010). The role of the predatory trahira (Pisces: Erythrinidae) in structuring fish assemblages in lakes of a Neotropical floodplain. Hydrobiologia 651, 115-126. doi: 10.1007/s10750010-0281-0

Petry, P., Bayley, P. B., and Markle, D. F. (2003). Relationships between fish assemblages. macrophytes and environmental gradients in the Amazon River floodplain. J. Fish. Biol. 63, 547-579. doi: 10.1046/j.1095-8649.2003.00169.x

R Core Team, (2020). R: A Language and Environment for Statistical Computing. Vienna: R Foundation for Statistical Computing.

Rodríguez, M. A., and Lewis, W. M. Jr. (1997). Structure of fish assemblages along environmental gradients in floodplain lakes of the Orinoco River. Ecol. Monogr. 67, 109-128.

Ruffino, M. L., and Issac, V. J. (2000). “Ciclo de vida e parâmetros biológicos de algumas espécies de peixes da Amazônia Brasileira," in Recursos Pesqueiros do Médio Amazonas: Biologia e Estatística Pesqueira (Coleção Meio Ambiente, Série Estudos Pesca. 22), ed. IBAMA, (Brasília: Ediçôes IBAMA), 11-30.

Russ, G. R., Alcala, A. C., Maypa, A. P., Calumpong, H. P., and White, A. T. (2004). Marine reserve benefits local fisheries. Ecol. Appl. 14, 597-606.

Sánchez-Botero, J. I., Garcez, D. S., and Vidal, M. D. (2010). Co-management of fishery resources in the floodplain communities of the middle and lower amazon river, Brazil. Sci. Mag. UAKARI 6, 45-55. doi: 10.31420/uakari.v6 i 2.94

Sant'anna, I. R., Doria, C. R. C., and Freitas, C. E. C. (2014). Pre-impoundment stock assessment of two Pimelodidae species caught by small-scale fisheries in the Madeira River (Amazon Basin - Brasil). Fish. Manag. Ecol. 21, 322-329. doi: $10.1111 /$ fme. 12082

Santos, G., Ferreira, E., and Zuanon, J. 2006). Peixes comerciais de Manaus. Editora Pr-Vrzea, Ibama, Manaus, Brasil: Editora INPA, 146.

Silva, I. M., Hill, N., Shimadzu, H., Soares, A. M. V. M., and Dornelas, M. (2015). Spillover effects of a community-managed marine reserve. PLoS One 10:e0111774. doi: 10.1371/journal.pone.0111774

Silvano, R. A., Hallwass, G., Juras, A. A., and Lopes, P. F. (2017). Assessment of efficiency and impacts of gillnets on fish conservation in a tropical freshwater fishery. Aquat. Conserv. 27, 521-533. doi: 10.1002/aqc.2687

Silvano, R. A., Hallwass, G., Lopes, P. F., Ribeiro, A. R., Lima, R. P., and Hasenack, H. (2014). Co-management and spatial features contribute to secure fish abundance and fishing yields in tropical floodplain lakes. Ecosystems 17, 271-285. doi: 10.1007/s10021-013-9722-8

Silvano, R. A., Ramires, M., and Zuanon, J. (2009). Effects of fisheries management on fish communities in the floodplain lakes of a Brazilian Amazonian Reserve. Ecol. Freshw. Fish. 18, 156-166. doi: 10.1111/j.1600-0633.2008.00 333.x

Soares, M. G. M., Freitas, C. E. C., and Oliveira, A. C. B. D. (2014). Assembleias de peixes associadas aos bancos de macrófitas aquáticas em lagos manejados da Amazônia Central, Amazonas, Brasil. Acta Amaz. 44, 143-152. doi: 10.1590/ S0044-59672014000100014

Soares, M. G. M., Costa, E. L., Siqueira-Souza, F. K., Anjos, H. D. B., Yamamoto, K. C., and Freitas, C. E. C. (2007). Peixes de lagos do médio rio Solimões. Manaus: EDUA, 176.

Souza, L. A., Freitas, C. E. C., and Souza, R. G. C. (2015). Relação entre guildas de peixes, ambientes e petrechos de pesca baseado no conhecimento tradicional de pescadores da Amazônia Central. Bol. Inst. Pesca. 41, 633-644. 
Sweke, E. A., Assam, J. M., Matsuishi, T., and Chande, A. I. (2013). Fish diversity and abundance of Lake Tanganyika: comparison between protected area (Mahale Mountains National Park) and unprotected areas. Int. J. Biodivers. 2013, 1-10. doi: 10.1155/2013/269141

Symes, D. (2006). Fisheries governance: a coming of age for fisheries social science? Fish. Res. 81, 113-117. doi: 10.1016/j.fishres.2006.06.015

Taphorn, D. C. (1992). The Characiform Fishes of the Apure River Drainage. Venezuela: BioLlania Edición Especial - No. 4. Monografias Cientificas del Museo de Ciencias Naturales, UNELLEZ - Guanara, estado Portuguesa, 4:1537.

Tejerina-Garro, F. L., Fortin, R., and Rodríguez, M. A. (1998). Fish community structure in relation to environmental variation in floodplain lakes of the Araguaia River, Amazon Basin. Environ. Biol. Fishes. 51, 399-410. doi: 10.1023/ A:1007401714671

Tonn, W. M., Paszkowski, C. A., and Holopainen, I. J. (1992). Piscivory and recruitment: mechanisms structuring prey populations in small lakes. Ecology 73, 951-958. doi: 10.2307/1940171

Villacorta-Correa, M. A., and Saint-Paul, U. (1999). Structural indexes and sexual maturity of tambaqui Colossoma macropomum (Cuvier, 1818)(Characiformes: Characidae) in Central Amazon, Brazil. Bras. J. Biol. 59, 637-652. doi: 10.1590/ S0034-71081999000400013
Welcomme, R. L. (1999). A review of a model for qualitative evaluation of exploitation levels in multi-species fisheries. Fish. Manag. Ecol. 6, 1-19. doi: 10.1046/j.1365-2400.1999.00 137.x

Welcomme, R. L., Cowx, I. G., Coates, D., Béné, C., Funge-Smith, S., and Halls, A. (2010). Inland capture fisheries. Philos. Trans. R. Soc. Lond. B Biol. Sci. 365, 2881-2896. doi: 10.1098/rstb.2010.0168

Wickham, H. (2016). ggplot2: Elegant Graphics for Data Analysis. New York, NY: Springer-Verlag New York.

Conflict of Interest: The authors declare that the research was conducted in the absence of any commercial or financial relationships that could be construed as a potential conflict of interest.

Copyright (C) 2021 Medeiros-Leal, Castello, Freitas and Siqueira-Souza. This is an open-access article distributed under the terms of the Creative Commons Attribution License (CC BY). The use, distribution or reproduction in other forums is permitted, provided the original author(s) and the copyright owner(s) are credited and that the original publication in this journal is cited, in accordance with accepted academic practice. No use, distribution or reproduction is permitted which does not comply with these terms. 